\title{
Identification of a Naturally Occurring Polymorphism in the Promoter Region of the Norepinephrine Transporter and Analysis in Major Depression
}

Peter Zill, Ph.D., Rolf Engel, Ph.D., Thomas C. Baghai, M.D., Georg Juckel, M.D., Thomas Frodl, M.D., Florian Müller-Siecheneder, M.D., Peter Zwanzger, M.D., Cornelius Schüle, M.D., Christo Minov, M.D., Stefanie Behrens, M.T.A., Rainer Rupprecht, M.D., Ulrich Hegerl, M.D., Hans Jürgen Möller, M.D., and Brigitta Bondy, M.D.

Disturbances in the noradrenergic neurotransmission system have been implicated in the etiology of mood disorders. The norepinephrine transporter (NET) is a main target of antidepressant action and was shown to be dysregulated in major depression. Despite the clinical and physiological significance of NET gene regulation, little is known about the transcriptional control mechanisms governing its expression. Since it is well established that affective disorders have a genetic component with many genes of small effect contributing to the genetic susceptibility of depression, the NET gene is an interesting candidate gene for affective disorders. In a search for polymorphisms or mutations in the 5' flanging region of the NET gene we sequenced approximately 1000 bp upstream of the first codon in the NET gene promoter in 100 patients with major depression and 100 healthy controls. We identified a so far unknown $T \rightarrow$ C polymorphism $182 \mathrm{bp}$ upstream of the start codon in a transcriptional relevant region. In a case control association study we investigated the newly identified T-182C polymorphism and an already known G1287A polymorphism in exon 9 of the NET gene in a sample of 193 patients with major depression and 136 healthy, non-related controls. No statistical significant differences between patients and controls were found for any of the analyzed polymorphisms, either in the genotype distribution or in the allele frequencies. Our results suggest that the investigated polymorphisms are not major susceptibility factors in the etiology of major depression. [Neuropsychompharmacology 26:489-493, 2002] (C) 2002 American College of Neuropsychompharmacology. Published by Elsevier Science Inc.
From the Psychiatric Hospital of the Ludwig-Maximilians-University, Munich, Nussbaumstr. 7, D-80336 Munich, Germany.

Address correspondence to: Dr. Peter Zill, Psychiatric Hospital of the Ludwig-Maximilians-University, Munich Nussbaumstr. 7 D-80336 Munich, Germany, Tel.: +49-89-51602741, Fax: +49-89-51604741, E-mail: Peter.Zill@psy.med.uni-muenchen.de

Received March 29, 2001; revised August 30, 2001; accepted September 20, 2001.

Online publication: 10/8/01 at www.acnp.org/citations/Npp 100801183
KEY WORDS: Norepinephrine; Polymorphisms; Major depression; Association study; Ppromoter

Monoamine neurotransmitters, particularly norepinephrine (NE) and serotonin play an important, possibly primary, role in pathophysiology and treatment of mood disorders. Many studies have reported altered NE levels in depressed patients (reviewed by Charney 1998). Studies of NE metabolites showed decreased urinary levels of MHPG (3-methoxy-4-hydroxyphenylglycol), 
the major metabolite of NE in unipolar patients, and elevated levels in bipolar patients during manic states (Maas et al. 1972; Muscettola et al. 1984). Investigations of NE metabolites in the cerebrospinal fluid (CSF) of depressed patients compared with healthy individuals led to so far conflicting results. The most consistent finding in the literature is that antidepressant treatment causes decreased NE turnover (DeBellis et al. 1993). This effect occurs consistently with selective NE-specific agents as expected, but also with selective serotonergic-specific agents and with electroconvulsive therapy (Owens 1997). Taken together, these results suggest a decrease in the release and/or production of NE in depressed individuals, which means that a complex dysregulation of the NE system appears to play an important role in the pathophysiology of affective disorders (review by Ressler and Nemeroff 1999). Additionally NE has been implicated in modulating mood, sleep, appetite and neuroendocrine functions, which are often disturbed in affective disorders (Kaye et al. 1990; Stoline 1996).

Norepinephrine functions are mediated by NE binding proteins such as adrenergic receptors and NE transporters. The NE transporter (NET) is a major target for psychoactive drugs such as neuroleptics, psychostimulants and antidepressants. These agents block NE transport via the NET, resulting in enhancement of the synaptic activity of NE. Recently Klimek et al. (1997) reported that the NET levels are reduced in the locus coeruleus in patients with major depression. Given that noradrenergic transmission can be regulated by changes in NET expression, it seems plausible that changes in the level of NET in the brain may contribute to central noradrenergic dysfunction putatively associated with major depression and/or treatment response.

Although environmental factors play an important role in the development of mental illness, there is strong evidence that affective disorders have a genetic component with many genes of small effect contributing to the genetic susceptibility of depression and the gene for the norepinephrine transporter could be a candidate gene for depression. The NET gene is located on chromosome 16q12.2; it spans approximately $45 \mathrm{~kb}$ and consists of 14 exons (Porzgen et al. 1995). Recently the sequence and structure of the $5^{\prime}$ flanking promoter region of the NET gene has been reported (Kim et al. 1999). The 5' flanking promoter region of the NET gene has a length of approximately $4.7 \mathrm{~kb}$ and contains several important cis-elements for transcription (Kim et al. 1999). Despite the clinical and physiological significance of NET gene regulation, little is known about the transcriptional control mechanisms governing its expression.

The aim of this study was to screen the promoter region for polymorphisms or mutations, which could affect the transcriptional activity of the NET gene. We sequenced approximately $1000 \mathrm{bp}$ upstream of the start codon, where most of the transcriptional important cis- elements are located. For sequencing, DNA of 100 patients with major depression and of 100 healthy controls was used. Finally, in a case control association study we evaluated whether there is a possible association between the newly identified polymorphisms and an additional silent polymorphism, a G1287A point mutation in exon 9 of the NET gene (Stöber et al. 1996) in a total sample of 193 patients with major depression and 136 healthy controls.

\section{MATERIALS AND METHODS}

\section{Subjects}

A total of 193 patients with major depression diagnosed according to ICD 10 and DSM IV criteria were included in the study (70 males, 123 females, mean age $50.4 \pm$ 12.9 years, range $21-80$ years). Severity of depression was assessed using the 17-item Hamilton Rating Scale for Depression (HAMD-17) and the Clinical Global Impression Scale (CGI). Only subjects with a minimum score of 18 on the HAMD-17 entered the study, and patients with coexisting substance abuse or severe organic disorders were excluded. In $22 \%$ of the patients it was the first episode of disease; the other $78 \%$ had several episodes (range $2-20$, mean $3.7 \pm 3.6$, two and three episodes being the most frequent).

The control group consisted of a sample of 136 healthy probands, recruited from the general population in southern Germany, who were psychiatrically screened using personality questionnaires to rule out psychiatric problems, were included in the study ( 64 males, 72 females, mean age $48.3 \pm 12.6$ years, range $22-76$ years).

All patients and controls gave informed and written consent to participate in the study.

\section{Sequencing}

Genomic DNA was isolated from whole blood according to standard procedures. We sequenced a DNA segment of $1140 \mathrm{bp}$ from position -996 in the $5^{\prime}$ region to position 45 in exon 1 (numbering based on GenBank, accession number AF061198; the adenosine of the ATG start codon is indicated as +1 ). Sequencing was performed by dividing the $1140 \mathrm{bp}$ region in two overlapping fragments, amplified by PCR with the following conditions. Forward primer 1 (pos. -996): 5'-GAT AGT TTA AGT GGC CTG CTG C-3'; reverse primer 1 (pos. -444): 5'-AAA CTC GCT AGC CCT CTG CT-3'; forward primer 2 (pos. -505): 5'-ACA GGG CTA GGT CTG CCT G-3'; reverse primer 2 (pos. 28): 5'-GTT GTT CTC GGG CTG CAC-3'. PCR was carried out in a final volume of $25 \mu \mathrm{l}$ containing 50 ng genomic DNA, $200 \mu \mathrm{M}$ of each dNTP, $100 \mu \mathrm{M}$ 7-deaza-GTP, $5 \%$ DMSO, $0.5 \mu \mathrm{M}$ of the forward and reverse primer and 1.25 units Hot Start Taq DNA polymerase. After an initial denaturation step of $95^{\circ} \mathrm{C}$ for 10 
min, there were 35 cycles of denaturation at $95^{\circ} \mathrm{C}$ for $30 \mathrm{~s}$, annealing at $68^{\circ} \mathrm{C}$ for $35 \mathrm{~s}$ and extension at $72^{\circ} \mathrm{C}$ for $45 \mathrm{~s}$. A final step was performed at $72^{\circ} \mathrm{C}$ for $7 \mathrm{~min}$. PCR products were purified with the Qiaquick PCR Purification Kit according to the manufacturer's instructions. $50 \mathrm{ng}$ of the purified PCR product was used for cycle sequencing with the BigDye Terminator chemistry (ABI Biosystems) in a final volume of $25 \mu \mathrm{l}, 8 \mu \mathrm{l}$ reaction mix and $3.2 \mathrm{pmol}$ primer. Results were verified by bi-directional sequencing. Cycling conditions were: 25 cycles of denaturation at $96^{\circ} \mathrm{C}$ for $10 \mathrm{~s}$, annealing at $50^{\circ} \mathrm{C}$ for $5 \mathrm{~s}$ and extension at $60^{\circ} \mathrm{C}$ for $4 \mathrm{~min}$. The amplified products were purified with Centri-Sep spin columns and sequenced on an ABI 310 capillary sequencer (ABI Biosystems).

\section{Genotyping}

All genotypings were performed by the fluorescence resonance energy transfer method (FRET) using the Light Cycler (Roche Diagnostics). A detailed description of the theoretical background and methodology is given by Toyota et al. (2000). For the two investigated polymorphisms the following conditions were applied. G1287A polymorphism (exon 9): forward primer: 5'TTC AGG GAG ACC CTA ATT CC-3'; reverse primer: 5'-TTG ACT TTA TTG AAA TGC GGC-3'; donor hybridization probe: 5'-GTC ATC ACG GGC CTG GCAfluorescein-3'; acceptor hybridization probe: 5'-LCRed 705-TGA CTT CCA GGT CCT GAA GC-3'. PCR was performed with $50 \mathrm{ng}$ DNA in a total volume of $20 \mu \mathrm{l}$ containing $2 \mu \mathrm{l}$ reaction mix, $0.5 \mu \mathrm{M}$ each primer, 0.2 $\mu \mathrm{M}$ each hybridization probe and $2 \mu \mathrm{M} \mathrm{MgCl}_{2}$ according to the manufacturer's instructions for 40 cycles of denaturation $\left(95^{\circ} \mathrm{C}, 0 \mathrm{~s}\right.$, ramp rate $\left.20^{\circ} \mathrm{C} / \mathrm{s}\right)$, annealing $\left(53^{\circ} \mathrm{C}, 10 \mathrm{~s}\right.$, ramp rate $\left.20^{\circ} \mathrm{C} / \mathrm{s}\right)$ and extension $\left(72^{\circ} \mathrm{C}, 10 \mathrm{~s}\right.$, ramp rate $20^{\circ} \mathrm{C} / \mathrm{s}$ ). After amplification a melting curve was generated by holding the reaction at $40^{\circ} \mathrm{C}$ for $20 \mathrm{~s}$ and then heating slowly to $95^{\circ} \mathrm{C}$ with a ramp rate of $0.2^{\circ} \mathrm{C} / \mathrm{s}$. The fluorescence signal was plotted against temperature to give melting curves for each sample. Peaks were obtained at $66^{\circ} \mathrm{C}$ for the G-allele and at $63^{\circ} \mathrm{C}$ for the A-allele. T-182C polymorphism ( $5^{\prime}$-region): forward primer: 5'-GAA CGA GGA AAA GTG CTG C-3'; reverse primer: 5'-TTG ACT TTA TTG AAA TGC GGC-3'; donor hybridization probe: 5'-GAC GCG CGC TCT TTT CTG GGA-fluorescein-3'; acceptor hybridization probe: 5'-LCRed640-CCC TGC GTC CGC TCA GCG CGC GCT CAT CCC-3'. PCR conditions were the same as for G1287A. Amplification was done for 40 cycles of denaturation $\left(95^{\circ} \mathrm{C}, 0 \mathrm{~s}\right.$, ramp rate $\left.20^{\circ} \mathrm{C} / \mathrm{s}\right)$, annealing $\left(60^{\circ} \mathrm{C}, 10 \mathrm{~s}\right.$, ramp rate $\left.20^{\circ} \mathrm{C} / \mathrm{s}\right)$ and extension $\left(72^{\circ} \mathrm{C}, 10 \mathrm{~s}\right.$, ramp rate $20^{\circ} \mathrm{C} / \mathrm{s}$ ). After amplification a melting curve was generated by holding the reaction at $55^{\circ} \mathrm{C}$ for $20 \mathrm{~s}$ and then heating slowly to $95^{\circ} \mathrm{C}$ with a ramp rate of $0.1^{\circ} \mathrm{C} / \mathrm{s}$. The $\mathrm{T}$-allele led to melting peaks at $68^{\circ} \mathrm{C}$, the C-allele at $65^{\circ} \mathrm{C}$.
All laboratory procedures were carried out blind to case control status.

\section{Statistical Analysis}

General statistical analyses were performed using SPSS for Windows (Version 9.0; SPSS; Chicago, IL). Haplotype estimation and their association with the disorder were calculated with the computer programs pm (Zhao et al. 2000) and eh (Xie and Ott 1993). Power was estimated with the help of Table 8 in Longman (2001).

\section{RESULTS}

Identification of a new polymorphism in the $5^{\prime}$ promoter region of the NET gene: A fragment of $1040 \mathrm{bp}$ of the NET gene upstream of the start codon in the $5^{\prime}$ flanking promoter region was PCR amplified in two overlapping pieces from genomic DNA and sequenced in 100 patients with major depression and 100 healthy controls to screen for new polymorphisms or mutations. Direct sequencing of the two amplified genomic DNA fragments revealed a new $\mathrm{T} \rightarrow \mathrm{C}$ polymorphism in the promoter region at position -182 (numbering based on GenBank, accession number AF061198; the adenosine of the ATG start codon is indicated as +1 ). All reactions were performed by bi-directional sequencing. The sequence surrounding the variant is: $5^{\prime}-\mathrm{GAC}$ GCGCGC(T/C)CTTTTCTGG. The T-182C polymorphism is a relative common base exchange with genotype frequencies of $50 \%$ (TT), 39\% (TC), 11\% (CC) and an allele frequency of $69 \%$ (T-allele) and 31\% (C-allele) in healthy controls.

\section{Case Control Association Study}

Primers surrounding the new T-182C polymorphism were created and further 93 patients and 36 healthy probands were genotyped for the new polymorphism using the fluorescence resonance energy transfer method (FRET). Additionally the already known G1287A polymorphism in exon 9 of the NET gene was also investigated. The results of the genotype distribution and allele frequencies for the two investigated polymorphisms in the NET gene in patients with major depression and healthy controls are summarized in Table 1, the estimated haplotypes in Table 2. No statistical significant differences were found for the allele or the genotype frequencies between patients and controls. T-182C: (genotypes: $p=.951, \chi^{2}=0.099, \mathrm{df}=2$; alleles: $p=.865$, $\mathrm{OR}=1.03,95 \%$ CI $0.74-1.49$, Fisher's Exact Test, two sided); G1287A: $p=.378, \chi^{2}=1.945, \mathrm{df}=2$; alleles: $p=$ $.305, \mathrm{OR}=1.20,95 \%$ CI 0.86-1.67, Fisher's Exact Test, two sided. We could not detect a linkage disequilibrium between the two polymorphisms, either in pa- 
tients $\left(\chi^{2}=1.11, \mathrm{df}=3, p=.77\right)$ or in controls $\left(\chi^{2}=\right.$ $1.59, \mathrm{df}=3, p=.66)$. Cases had similar haplotype frequencies as controls $\left(\chi^{2}=1.94, \mathrm{df}=4, p=.75\right.$, m;odel free analysis). To detect a main effect for each polymorphism with a relative risk of 2 or greater in an additive mode, given the disorder related gene frequency of 0.30 , a test size of $\alpha=0.05$ and a power of 80 percent, a sample size of 193 subjects would have been large enough. A joint effect of both polymorphisms could have been detected with an even smaller number of subjects.

\section{DISCUSSION}

The NET gene is an interesting candidate gene, which contributes to the susceptibility for major depression and the response to antidepressant treatment. The findings that the expression of the NET gene is altered in the brain of depressed patients compared with healthy controls (Klimek et al. 1997) and its role as pharmacological target for antidepressants support the theory that the NET gene might be involved in the pathophysiology of depression. It is important to note that to our knowledge in only one study were several non-functional polymorphisms in the coding region of the NET gene reported (Stöber et al. 1996). Little is known about possible transcriptional mechanisms leading to changes in the expression of the NET gene. Because of these links we performed a sequencing scan of the $5^{\prime}$ flanking promoter region of the NET gene in patients with major depression and healthy controls. We identified a so far unknown $\mathrm{T} \rightarrow \mathrm{C}$ point mutation $182 \mathrm{bp}$ upstream of the first codon. The $5^{\prime}$ flanking promoter region first de-

Table 1. Genotype Distribution and Allele Frequencies of the T-182C and G1287A Polymorphisms in the Promoter Region of the NET Gene among Patients with Major Depression and Controls (Percentages in Parentheses)

\begin{tabular}{|c|c|c|c|c|c|c|}
\hline & \multicolumn{4}{|c|}{ Genotypes } & \multicolumn{2}{|c|}{$\begin{array}{c}\text { Allele } \\
\text { Frequencies }\end{array}$} \\
\hline & $\mathbf{N}$ & TT & TC & $\mathrm{CC}$ & $\mathrm{T}$ & $\mathrm{C}$ \\
\hline \multicolumn{7}{|l|}{$\mathrm{T}-182 \mathrm{C}$} \\
\hline Major Depression & 193 & $94(49)$ & $77(40)$ & $22(11)$ & 0.69 & 0.31 \\
\hline \multirow[t]{2}{*}{ Controls } & 136 & $66(50)$ & $53(39)$ & $17(11)$ & 0.68 & 0.32 \\
\hline & & GG & GA & AA & G & A \\
\hline G1287A & & & & & & \\
\hline Major Depression & 193 & $101(53)$ & $70(36)$ & $22(11)$ & 0.70 & 0.30 \\
\hline Controls & 136 & $61(44)$ & $59(44)$ & $16(12)$ & 0.66 & 0.34 \\
\hline
\end{tabular}

T-182C: Genotypes: $\mathrm{p}=0.951, \chi^{2}=0.099, \mathrm{df}=2$

Alleles: $\mathrm{p}=0.865(\mathrm{OR}=1.03,95 \%$ CI $0.74-1.49$, Fisher's Exact Test two sided) G1287A: Genotypes: $\mathrm{p}=0.378, \chi^{2}=1.945, \mathrm{df}=2$

Alleles: $\mathrm{p}=0.305$ (OR $=1.20,95 \%$ CI $0.86-1.67$, Fisher's Exact Test two sided)
Table 2. Estimated Haplotype Frequencies of the T-182C and G1287A Polymorphisms in the NET Gene among Patients with Major Depression and Controls under the Assumption of Linkage Disequilibrium (Association) or Non Linkage Disequilibrium (No Association) between the Alleles

\begin{tabular}{lccccc}
\hline & \multicolumn{2}{c}{ Patients } & & \multicolumn{2}{c}{ Controls } \\
\cline { 2 - 3 } \cline { 5 - 6 } Haplotypes & $\begin{array}{c}\text { no } \\
\text { association }\end{array}$ & association & & $\begin{array}{c}\text { no } \\
\text { association }\end{array}$ & association \\
\hline C, A & 0.093 & 0.108 & & 0.107 & 0.086 \\
C, G & 0.220 & 0.206 & & 0.213 & 0.234 \\
T, A & 0.203 & 0.187 & & 0.228 & 0.248 \\
T, G & 0.484 & 0.499 & & 0.453 & 0.432 \\
\hline
\end{tabular}

scribed by Kim et al. (1999) comprises approximately $4.7 \mathrm{~kb}$ and contains an additional intron of $476 \mathrm{bp}$. In this intron several potential transcriptional elements are located, which seem to have an important meaning as enhancer of transcription and correct splicing (Kim et al. 1999). The $T \rightarrow C$ point mutation lies in this intron and is located $20 \mathrm{bp}$ downstream of a CCAAT-box, $84 \mathrm{bp}$ downstream of a SP1 binding site and $98 \mathrm{bp}$ downstream of a binding site for the transcription factor C/EBP. A polymorphism in this region could probably lead to an altered transcriptional activity by changes in the DNA structure. Many other genes are known to have polymorphisms in their promoter region, not directly in ciselements, but neighboring altering the transcriptional activity (e.g. Tarkowski et al. 2000). Therefore we cannot exclude this possibility also for the T-182C polymorphism, but further studies of the promoter activity in dependence of this gene variant are needed to analyze potential effects on NET expression.

In order to determine a possible role of the $\mathrm{T}-182 \mathrm{C}$ polymorphism in the development of major depression we performed a case control association study with 155 depressed patients and 136 healthy controls. Additionally a silent polymorphism in exon 9 of the NET gene (G1287A) was also genotyped. Our study failed to detect an association between the two investigated polymorphisms and major depression or the response to antidepressant treatment evaluated by the 17-item Hamilton Score. These results are in concordance with previously reported findings. Stöber et al. (1996) found no evidence for an association between major depression and five missense mutations, including the G1287A polymorphism in the coding region of the NET gene. Another study investigated the G1287A polymorphism in a sample of 105 patients with major depression and 74 unrelated matched controls with negative results (Owen et al. 1999). Hadley et al. (1995) detected no linkage between NET gene polymorphisms and bipolar disorder. Taken together these results make it very improbable that the NET gene has a major effect (i.e. a relative risk of 2 or 
more) on depression. However, we cannot exclude a minor contribution of the NET gene in the pathophysiology of major depression, because the sample size of the present study does not provide statistical power to detect differences of small effect size. Although our samples were from the same geographical area the effect of ethnic stratification cannot be excluded. Moreover, the genetic contribution of depression is attributable to multiple genes with incomplete penetrance, each of small effect, and only large samples of patients and controls may show evidence for association or linkage if the effect size is small.

In summary our findings that genetic variants of the NET gene are not causally related to major depression should be replicated in different population samples and family studies. Especially the new identified T-182C polymorphism in the 5' flanking promoter region of the NET gene would require further investigations of the pattern of NET expression in dependence of the genotype to confirm the results of this study. Finally, future research might seek to uncover new functional NET gene variants in coding or promoter regions.

\section{ACKNOWLEDGMENTS}

This project is supported by the German Federal Research Ministry within the promotional emphasis "Competence Nets in Medicine."

\section{REFERENCES}

Charney DS (1998): Monoamine dysfunction and the pathophysiology and treatment of depression. J Clin Psychiatry 59(Suppl 14):11-14

DeBellis M, Geracioti T, Altemus M (1993): Cerebrospinal fluid monoamine metabolites in fluoxetine-treated patients with major depression and in healthy volunteers. Biol Psychiatry 33:636-641

Hadley D, Hoff M, Holik J, Reimherr F, Wender P, Coon H, Byerley W (1995): Manic-depression and the norepinephrine transporter gene. Hum Hered 45:165-168

Kaye WH, Ballenger JC, Lydiard RB, Stuart GW, Laraia MT, O'Neil P, Fossey MD, Stevens V, Lesser S, Hsu G (1990): CSF monoamine levels in normal-weight bulimia: evidence for abnormal noradrenergic activity. Am J Psychiatry 147:225-229

Kim CH, Kim HS, Cubells JF, Kim KS (1999): A previously undescribed intron and extensive 5 ' upstream sequence, but not Phox2a-mediated transactivation, are necessary for high level cell type-specific expression of the human norepinephrine transporter gene. J Biol Chem 274:65076518

Klimek V, Stockmeier C, Overholser J, Meltzer HY, Kalka S, Dilley G, Ordway GA (1997): Reduced levels of norepinephrine transporters in the locus coeruleus in major depression. J Neurosci 17:8451-8458

Longman JA (2001): Complexity and power in case-control association studies. Am J Hum Genet 68:1229-1237

Maas JW, Fawcett JA, Dekirmenjian H (1972): Catecholamine metabolism, depressive illness, and drug response. Arch Gen Psychiatry 26:252-262

Muscettola G, Potter WZ, Pickar D, Goodwin FK (1984): Urinary 3-methoxy-4-hydroxyphenylglycol and major affective disorders. A replication and new findings. Arch Gen Psychiatry 4:337-342

Owen D, Du L, Bakish D, Lapierre YD, Hrdina PD (1999): Norepinephrine transporter gene polymorphism is not associated with susceptibility to major depression. Psychiatry Res 87:1-5

Owens MJ (1997): Molecular and cellular mechanisms of antidepressant drugs. Depress Anxiety 4:153-159

Porzgen P, Bonisch H, Bruss M (1995): Molecular cloning and organization of the coding region of the human norepinephrine transporter gene. Biochem Biophys Res Commun 215:1145-1150

Ressler KJ, Nemeroff CB (1999): Role of norepinephrine in the pathophysiology and treatment of mood disorders. Biol Psychiatry 46:1219-1233

Stöber G, Nothen MM, Porzgen P, Bruss M, Bonisch H, Knapp M, Beckmann H, Propping P (1996): Systematic search for variation in the human norepinephrine transporter gene: identification of five naturally occurring missense mutations and study of association with major psychiatric disorders. Am J Med Genet 67:523-532

Stoline AM (1996): To sleep-perchance to dream of affective disorders. Am J Psychiatry 153:134-135

Tarkowski E, Liljeroth AM, Nilsson A, Ricksten A, Davidsson P, Minthon L, Blennow K (2000): TNF gene polymorphism and its relation to intracerebral production of TNFalpha and TNFbeta in AD. Neurology 54:2077-2081

Toyota T, Watanabe A, Shibuya H, Nankai M, Hattori E, Yamada K, Kurumaji A, Karkera JD, Detera-Wadleigh SD, Yoshikawa T (2000): Association study on the DUSP6 gene, an affective disorder candidate gene on $12 q 23$, performed by using fluorescence resonance energy transfer-based melting curve analysis on the LightCycler. Mol Psychiatry 5:489-494

Xie X, Ott J (1993): Testing linkage disequilibrium between a disease gene and marker loci. Am J Hum Genet 53:1107

Zhao JH, Curtis D, Sham PC (2000): Model-free analysis and permutation test for allelic associations. Hum Hered 50:133-139 